\title{
EDUKASI PENGELOLAAN SAMPAH DOMESTIK DALAM MEWUJUDKAN KAMPUNG HIJAU MANDIRI DI RT 01 RW 06 KELURAHAN KREO TANGERANG
}

\author{
Sandra Madonna ${ }^{1 *}$, Prismita Nursetyowati ${ }^{1}$, Astrid Dewi M. Sugiana ${ }^{2}$, Tita Djuitaningsih $^{3}$ \\ ${ }^{1}$ Program Studi Teknik Lingkungan, Fakultas Teknik dan Ilmu Komputer, \\ ${ }^{2}$ Program Studi IImu Politik, ${ }^{3}$ Program Studi Akuntansi, Fakultas Ekonomi dan IImu Sosial, \\ Universitas Bakrie, Indonesia \\ E-mail: sandra.madonna@bakrie.ac.id*, prismita.nursetyowati@bakrie.ac.id, \\ astrid.sugiana@bakrie.ac.id, tita.djuitaningsih@bakrie.ac.id
}

Received: June 10, 2020 / Revised: October 8, 2020 / Accepted: December 25, 2020

DOI: https://doi.org/10.36782/ijsr.v2i2.36

\begin{abstract}
ABSTRAK
Kampung Hijau Mandiri merupakan Program Pemerintah Kota Tangerang dalam rangka meningkatkan kesadaran masyarakat menjadikan lingkungan bersih, hijau dan asri. Terdapat 98 Kampung Hijau Mandiri yang tersebar di Tangerang, salah satunya di RT 01 RW 06 Kelurahan Kreo. Kriteria Kampung Hijau Mandiri yaitu kampung yang sehat nyaman dan bersih. Kelurahan Kreo salah satu kelurahan dengan jumlah penduduk yang padat di Tangerang, dengan jumlah 22.837 jiwa. Jumlah penduduk yang besar berkontribusi terhadap peningkatan timbulan sampah. Hasil observasi lapangan diperkirakan jumlah timbulan sampah RT 01 RW 06 Kelurahan Kreo sekitar 2.040 liter/hari, angka ini termasuk besar, sehingga perlu dikelola dengan baik. Pengelolaan sampah yang ada masih konvensional dengan sistem kumpul-angkutbuang. Potensi ekonomi dari sampah organik dan non-organik belum dimanfaatkan secara optimal. Pengelolaan sampah melalui sistem pemilihan dan reduksi sampah di sumber dapat dilakukan. Pengolahan sampah organik secara komposting menggunakan Keranjang Takakura dan pengelolaan sampah non organik melalui Bank Sampah diperkenalkan untuk mengatasi sampah rumah tangga. Kegiatan Edukasi Pengelolaan sampah rumah tangga ini dihadiri oleh warga khususnya ibu-ibu rumah tangga dan kader posyandu sebanyak 14 orang, materi disampaikan melalui presentasi, praktik dan diskusi tanya jawab. Kemungkinan keberlanjutan dari kegiatan ini sangat besar karena para ibu rumah tangga dan kader posyandu sebagai pemangku kebijakan di rumah tangga yang berpengaruh di lingkungannya. Dari kegiatan ini warga pun bersepakat untuk mendirikan Bank Sampah. Keterlibatan sebagian warga dapat menjadi motivator bagi warga lainnya dalam mengelola sampah, sehingga dapat mewujudkan RT 01 RW 06 Kelurahan Kreo menjadi Kampung Hijau Mandiri yang bersih, hijau dan asri.
\end{abstract}

Kata kunci: Bank Sampah, Kampung Hijau Mandiri, Kelurahan Kreo, Keranjang Takakura, Sampah Rumah Tangga.

\section{ABSTRACT}

Kampung Hijau Mandiri is one of Tangerang Government's Programs to increase public awareness for a clean, green, and beautiful surrounding. Ninety-eight of Kampung Hijau Mandiri were formed throughout Tangerang's Sub-Districts, one of which is in RT 01 RW 06, 
Kreo Sub-District. Criteria for Kampung Hijau Mandiri include a lively, comfortable and clean village with waste sorting initiatives. Kreo, one of the densely populated villages in Tangerang, has 22,837 inhabitants. Waste generated in RT 01 RW 06, Kreo, Tangerang is around 2,040 liters/day, quite large and can be reduced. Presently, household wastes in RT 01 RW 06 are still managed conventionally using the collection and disposal system. The economic potential of household organic and inorganic waste has not been optimally utilized. Organic waste management through composting (Takakura baskets) and non-organic waste management through waste banks are considered appropriate for processing household wastes. Hence, the community develops a new habit of sorting and processing waste into productive means, reducing waste generation transported to landfills. The waste management educational mentoring program was attended by 14 people, especially housewives and Posyandu cadres, through presentations and question and answer. This activity has great potential to endure as housewives and Posyandu cadres in RT 01 RW 06 Kreo Sub-District are influential household stakeholders in their environment. Residents of RT 01 RW 06 Kreo Sub-District agreed to initiate waste bank establishments. This program is expected to increase citizen's involvement in waste management. RT 01 RW 06 Kreo is an exemplary Kampung Hijau Mandiri.

Keywords: Household Waste, Kampung Hijau Mandiri, Kreo Village, Takakura Basket, Waste Banks.

\section{PENDAHULUAN}

Pengelolaan sampah domestik yang masih kurang mempedulikan faktor non teknis seperti keterlibatan masyarakat dalam penyuluhan mengenai hidup sehat dan bersih, menjadi penyebab timbulnya permasalahan dan hambatan dalam proses pengelolaan sampah di kota-kota besar seperti Tangerang. Kampung Hijau merupakan Program Pemerintah Kota Tangerang melalui Dinas Lingkungan Hidup (DLH), dalam rangka meningkatkan kesadaran masyarakat agar tercipta lingkungan yang bersih, hijau dan asri. Telah dibentuk sembilan puluh delapan (98) Kampung Hijau yang tersebar di seluruh kecamatan di Tanggerang salah satunya di RT 01 RW 06 Kelurahan Kreo Tangerang. Menurut Eny Nuraeny Kabid Penaatan dan Peningkatan Kualitas Lingkungan Hidup pada DLH Kota Tangerang, kriteria Kampung Hijau yakni sehat, nyaman dan bersih, melalui proses pembinaan berlanjut sampai bisa menciptakan kekhasan di lingkungan serta dapat melakukan pemilahan sampah (tangerangkota.go.id., 2018). Kelurahan Kreo merupakan salah satu kelurahan dengan jumlah penduduk yang besar di Kota Tangerang penduduk 22.837 jiwa di tahun 2018 (Badan Pusat Statistik Kota Tangerang, 2018). Jumlah penduduk yang besar ini dengan keanekaragaman aktivitas sangat berkontribusi terhadap peningkatan permasalahan sampah yang muncul seiring dengan peningkatan timbulan sampah yang menyertainya. Berdasarkan hasil pengamatan di lokasi kegiatan yang dilakukan oleh tim Pengabdian kepada Masyarakat (PkM), dapat diperkirakan jumlah timbulan sampah di RT 01 RW 06 Kelurahan Kreo, Tangerang mencapai 
2.040 liter per hari, angka ini cukup besar dan berpotensi untuk dikelola dengan baik.

Pengelolaan sampah yang baik merupakan salah satu kriteria Kampung Hijau. Menurut Soemirat (2011) terdapat sepuluh kendala pengelolaan sampah di masyarakat, lima diantaranya disebutkan berikut ini,

1) Kebiasaan pengelolaan sampah yang tidak efisien, tidak benar sehingga menimbulkan pencemaran lingkungan,

2) Kegagalan dalam mendaur ulang atau pemanfaatan kembali barang bekas,

3) Sukarnya menyimpan sementara sampah organik yang cepat membusuk,

4) Sulitnya mengajak masyarakat untuk berpartisipasi dalam memelihara kebersihan lingkungan, dan

5) Pengelolaan sampah saat ini kurang memperhatikan faktor non teknis seperti partisipasi masyarakat dan penyuluhan tentang hidup sehat dan bersih (Soemirat,2011).

Peran serta masyarakat dalam mengelola sampah mulai dari rumah tangga sangat diharapkan mengatasi permasalahan sampah ini. Penanganan sampah secara keseluruhan diperlukan agar limbah tersebut tidak mengganggu kesehatan, estetika, dan lingkungan. Penanganan tersebut mencakup cara memindahkan dari sumbernya, mengolah, dan mendaur-ulang kembali.
Kegiatan pengabdian masyarakat ini menggunakan dua pendekatan yaitu pendekatan secara teknologi dengan memperkenalkan teknologi komposting Takakura dalam pengolahan sampah organik melalui pelatihan pengolahan sampah rumah tangga dan pendekatan secara sosial dengan melakukan sosialisasi sistem pengelolaan sampah rumah tangga dan komunal melalui pembentukan Bank Sampah serta memperkenalkan Bank Sampah kepada masyarakat RT 01 RW 06 Kelurahan Kreo.

\section{TINJAUAN PUSTAKA}

\section{A.Pengelolaan Sampah Rumah Tangga}

Menurut Damanhuri, E. \& Padmi, T. (2015), hanya $60 \%$ sampah yang berasal dari kota-kota besar di Indonesia dapat terangkut ke tempat pembuangan sampah akhir (TPA). Pengelolaan sampah adalah kegiatan yang sistematis, menyeluruh, dan berkesinambungan yang meliputi pengurangan dan penanganan sampah. Menurut Undang Undang No. 18 Tahun 2008 tentang Pengelolaan Sampah, disebutkan bahwa pengelolaan sampah rumah tangga dan sampah sejenis sampah rumah tangga terdiri atas 2 cara yaitu: 1). Pengurangan sampah; dan 2). Penanganan sampah. Menurut Peraturan Menteri Pekerjaan Umum Republik Indonesia Nomor 03/Prt/M/2013 tentang Penyelenggaraan Prasarana dan Sarana Persampahan dalam Penanganan Sampah Rumah Tangga dan Sampah Sejenis Sampah 
Rumah Tangga, disebutkan bahwa penanganan sampah meliputi berbagai kegiatan, seperti:

1. Pemilahan;

2. Pengumpulan;

3. Pengangkutan;

4. Pengolahan; dan

5. Pemrosesan akhir sampah

(Peraturan Menteri Pekerjaan Umum RI Nomor 03/Prt/M/2013)

Pengelolaan sampah bertujuan untuk meningkatkan kesehatan masyarakat dan kualitas lingkungan serta menjadikan sampah sebagai sumber daya. Pengertian pengelolaan bukan hanya menyangkut aspek teknis, tetapi mencakup juga aspek non teknis, seperti mengorganisir, bagaimana membiayai dan melibatkan masyarakat penghasil limbah agar ikut berpartisipasi secara aktif atau pasif dalam aktivitas penanganan tersebut.

Pengertian sampah rumah tangga menurut Undang-undang Pengelolaan Sampah Nomor 18 Tahun 2008, adalah sampah yang berasal dari kegiatan sehari-hari dalam rumah tangga, tidak termasuk tinja dan sampah spesifik. Sampah sejenis sampah rumah tangga adalah sampah yang berasal dari kawasan komersial, kawasan industri, kawasan khusus, fasilitas sosial, fasilitas umum, dan/atau fasilitas lainnya.

Menurut Peraturan Pemerintah Republik Indonesia Nomor 81 tahun 2012 tentang Pengelolaan Sampah Rumah Tangga Dan Sampah Sejenis Sampah Rumah Tangga, disebutkan bahwa masyarakat berperan serta dalam proses pengambilan keputusan, penyelenggaraan, dan pengawasan dalam kegiatan pengelolaan sampah rumah tangga dan sampah sejenis sampah rumah tangga yang diselenggarakan oleh pemerintah dan/atau pemerintah daerah. Peran serta masyarakat sebagaimana dimaksud dapat ditujukan melalui pelaksanaan kegiatan penanganan sampah rumah tangga dan sampah sejenis sampah rumah tangga yang dilakukan secara mandiri dan/atau bermitra dengan pemerintah kabupaten/kota; dan/atau pemberian pendidikan dan pelatihan, kampanye, dan pendampingan oleh kelompok masyarakat kepada anggota masyarakat dalam pengelolaan sampah untuk mengubah perilaku anggota masyarakat.

\section{B.Pengolahan Sampah Rumah Tangga}

Sampah domestik atau sampah rumah tangga sebagian besar merupakan sampah organik. Metode pengomposan sangat tepat digunakan untuk mengolah sampah organik

Salah satu metode pengomposan sampah organik atau sampah dapur adalah dengan menggunakan Keranjang Takakura. Keranjang Takakura dirancang untuk beroperasi pada tempat yang kecil seperti dapur dan halaman sehingga sangat ideal untuk rumah tangga (Kurniawan dkk., 2013).

Pengomposan dengan Keranjang Takakura merupakan cara praktis dalam pengelolaan 
sampah karena sangat cocok untuk perumahan dengan lahan yang terbatas. Selain itu, metode ini mudah digunakan karena hanya memasukkan sampah setiap harinya, tanpa ada perlakukan khusus seperti menambahkan bahan-bahan tambahan lain. Menurut Madonna \& Nursetyowati (2019), dengan Keranjang Takakura sampah dapat dikelola dengan mudah, dapat diterapkan di rumah tangga sehari-hari, tanpa memerlukan lahan yang luas, prosesnya cepat, dan kompos yang dihasilkan tidak berbau.

Pengenalan teknologi pengolahan sampah kepada masyarakat yang bersifat sederhana, mudah, murah, efisiean dapat mengedukasi dan menambah wawasan masyarakat, sehingga menimbulkan kesadaran dan kemauan masyarakat untuk mengelola sendiri sampahnya mulai dari sumber atau mulai dari rumahnya masing-masing. Pengenalan cara-cara sederhana yang mudah diterapkan dalam pengolahan sampah sangat diperlukan sehingga secara langsung masyarakat dapat melakukannya di lingkungan (Tchobanoglous, 1993).

\section{METODOLOGI KEGIATAN}

Kegiatan pengabdian masyarakat ini menggunakan metode penyampaian secara langsung melalui presentasi mengenai pengelolaan sampah rumah tangga, pengenalan konsep 3R (Reduce, Reuse, Recycle), serta pengenalan Bank Sampah. Praktik pengolahan sampah organik atau sampah dapur dilakukan dengan metode Keranjang Takakura, dan dilanjutkan dengan diskusi dan tanya jawab.

Pelatihan pengolahan sampah dapur menjadi kompos dengan metode Takakura terdiri dari tiga tahap pengerjaan yaitu:

1. Tahap pertama di dahului dengan membuat cairan fermentasi, yang akan digunakan sebagai starter mikroba yang terdiri dari bakteri dan jamur yang berperan sebagai dekomposer atau pengurai sampah organik. Cairan ini berisi campuran makanan fermentasi dan air gula, dan kulit buah atau sayur dan air garam

2. Tahap kedua yaitu mempersiapkan komposter Takakura yang dilengkapi dengan fermenting bed atau lapisan dasar fermentasi dapat berupa sekam padi yang telah dicampur cairan fermentasi yang telah disiapkan pada tahap satu sebelumnya. Selama proses fermentasi dilakukan pengaturan kelembaban media.

3. Tahap ketiga mencampur sampah organik ke dalam komposter yang sebelumnya sampah tersebut terlebih dahulu sudah dicacah untuk mempercepat proses pengomposan. Setelah kompos terbentuk, kompos dapat dipisahkan dari Keranjang Takakura kemudian dimatangkan dengan menyimpannya di dalam kardus selama 2 minggu sebelum dipanen untuk digunakan. (Japan International Cooperation Agency) 


\section{PEMBAHASAN}

A. Presentasi Pengelolaan Sampah Rumah Tangga, Pengenalan Konsep 3R dan Bank Sampah

Kegiatatan pengabdian masyarakat yang dihadiri oleh 14 ibu rumah tangga dan kader posyandu ini didahului dengan penyampaian materi secara langsung melalui presentasi. Presentasi menerangkan Sistem Pengelolaan Sampah di Rumah Tangga, menjelaskan alasan mengapa sampah harus dikelola mulai dari sumber, menjelaskan dampak sampah yang tidak dikelola dengan baik terhadap kesehatan dan lingkungan. Dalam kegiatan ini dijelaskan pula cara pengelolaan sampah rumah tangga, mulai memilah sampah kemudian mengelompokannya berdasarkan tiga jenis sampah yaitu sampah organik atau sampah basah, sampah anorganik dan sampah yang mengandung bahan berbahaya dan beracun (B3).

Presentasi ditutup dengan penjelasan mengenai bagaimana mengolah sampah dari masing-masing kelompok tersebut yang dapat dilakukan di rumah tangga. Suasana saat berlangsung kegiatan presentasi terlihat pada Gambar 1. Warga masyarakat RT 01 RW 06, Kelurahan Kreo Tangerang khususnya ibu-ibu rumah tangga dan ibu-ibu kader Posyandu terlihat sangat antusias dalam berdiskusi, dan bertanya. Sebagian peserta ingin melakukan pengelolaan sampah di rumahnya masingmasing.
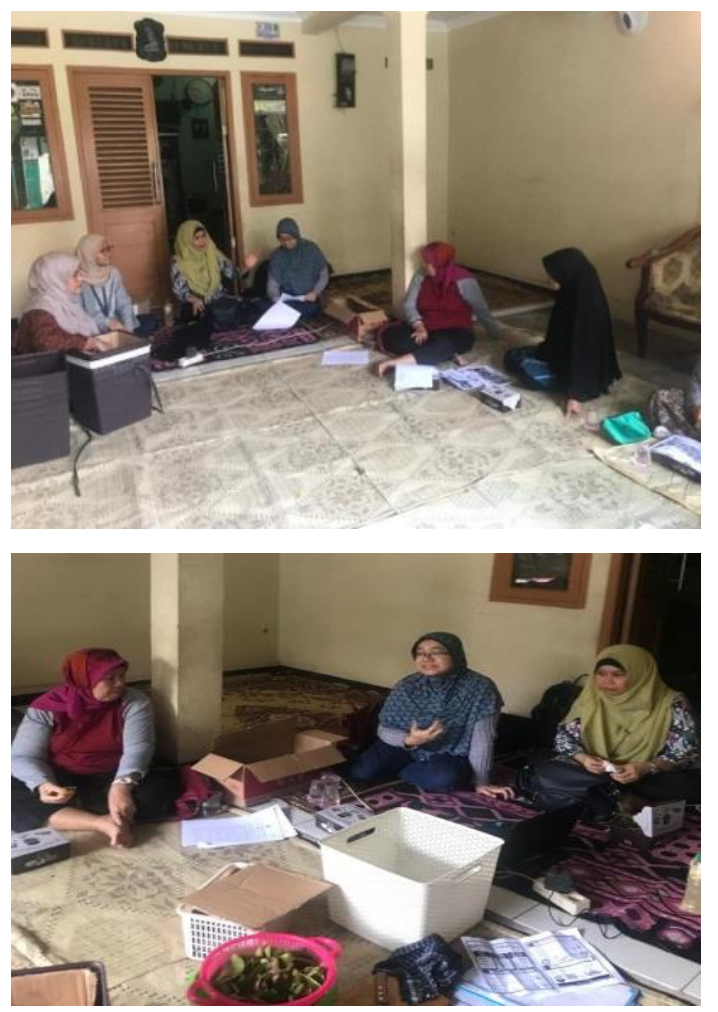

Gambar 1. Presentasi Pengelolaan Sampah Rumah Tangga Pengenalan Konsep 3R dan Bank Sampah (Sumber: dokumentasi penulis)

Pengolaan dapat dilakukan dengan mengolah sampah dapur berupa sisa-sisa potongan sayur, kulit buah, sisa-sisa makanan untuk dijadikan kompos dengan metoda Takakura. Pengolahan sampah ini dapat langsung dilakukan di keranjang sampah dapur mereka. Peserta berkeinginan mendaur ulang sampah anorganik dan mengelolaannya dengan membentuk serta mengelola Bank sampah yang baik untuk kedepannya yang dapat mewujudkan cita-cita warga menjadikan lingkungannya sebagai kampung hijau mandiri yang bebas dari sampah, sehat, bersih dan nyaman.

\section{B. Praktik Pengolahan Sampah Organik}

Praktik Pengolahan Sampah Organik dilakukan dengan metoda Takakura, dengan 
mengolah sampah dapur berupa sayur-sayuran dan kulit buah menjadi kompos dalam keranjang sampah.

Sebelum Praktik pengolahan sampah organik dilakukan setiap peserta diminta membawa sampah dari sisa dari potonganpotongan sayur yang berasal dari dapur mereka. Setiap peserta mendapatkan komposter berupa Keranjang Takakura yang dibagikan oleh Tim PKM. Kegiatan edukasi pengelolaan sampah domestik ini disertai dengan pelatihan mulai dengan mempraktikan bagaimana cara memilah sampah organik, anorganik dan sampah bahan berbahaya beracun yang berasal dari rumah tangga, informasi pemilihan ini diberikan khususnya pemilahan bahan organik yang akan dijadikan kompos, karena tidak semua sampah dapur atau sampah organik bisa digunakan untuk membuat kompos. Selanjutnya peserta melakukan praktik pembuatan cairan starter bakteri untuk membuat kompos yang juga berasal dari sampah tersebut.

Cairan starter terdiri dari dua buah larutan berupa cairan bakteri A dan cairan bakteri B yang membedakan keduanya berupa komposisi media yang digunakan yang mendukung pertumbuhan mikroba yang akan digunakan dalam mengurai sampah organik menjadi kompos. Pelatihan berikutnya mempraktekan cara membuat komposter berupa Keranjang Takakura yang sederhana. Keranjang Takakura ini pula dapat memanfaatkan keranjang sampah dapur yang sudah ada, pada kegiatan ini diterangkan bagaimana susunan lapisan-lapisan dasar Keranjang Takakura untuk menjaga kelembaban dalam proses pembuatan kompos. Praktik pembuatan komposter ini diakhiri dengan praktik mencampur sampah dapur yang memenuhi syarat untuk dijadikan kompos dengan larutan starter bakteri A dan bakteri B ke dalam Keranjang Takakura. Pada pelatihan ini juga diterangkan bagaimana kondisi lingkungan media komposter yang harus dijaga kondisinya agar proses pembuatan kompos ini dapat berlangsung optimum, cepat dan menghasilkan kompos yang baik dan siap digunakan.

Hasil pembuatan kompos menggunakan Keranjang Takakura diperlihatkan pada pelatihan ini sehingga peserta dapat mengetahui dengan melihat bagaimana kompos yang sudah matang dan baik kualitasnya, diantaranya tidak berbau dan berbentuk seperti tanah. Dokumentasi fotofoto kegiatan saat praktik pengolahan sampah organik menggunakan Keranjang Takakura terlihat pada Gambar 2.

Dari hasil diskusi dan tanya jawab masyarakat mengetahui bagaimana mengelola sampah rumah tangga, serta mengetahui bagaimana cara mengolah sampah dapur dengan Keranjang Takakura serta bagaimana pengaplikasian konsep 3R dan Bank Sampah, sehingga dengan kegiatan ini diharapkan timbulan sampah yang akan diangkut ke TPA Rawa Kucing Tangerang dari lingkungan RT 01 RW 06 setiap hari akan berkurang. 

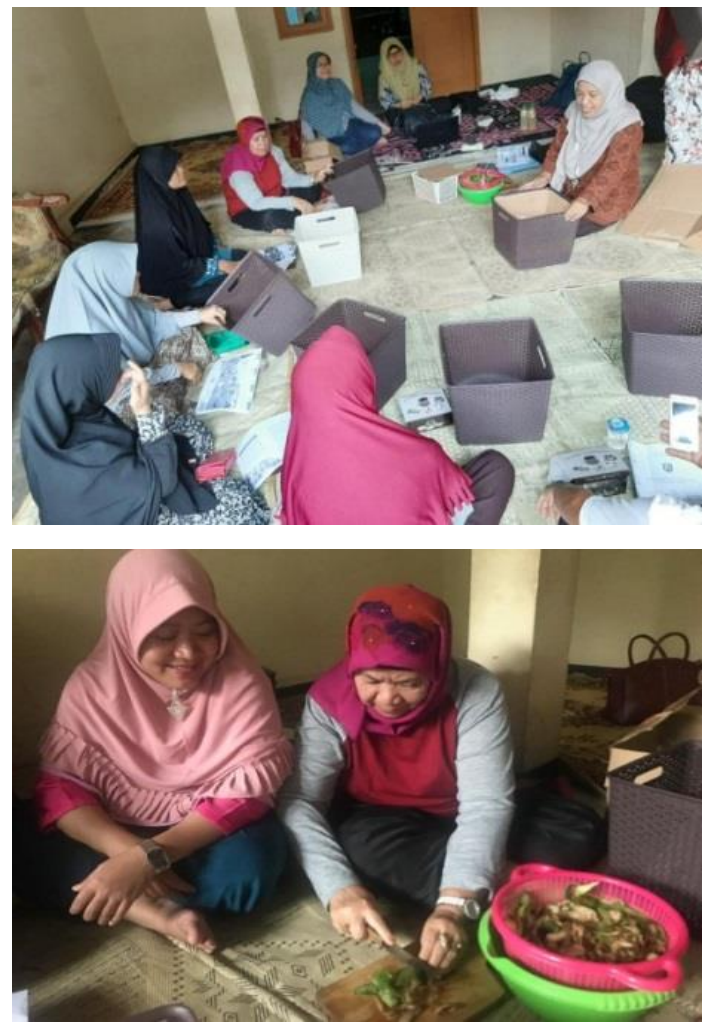

Gambar 2. Praktik Pengolahan Sampah Organik dengan Metoda Keranjang Takakura

(Sumber: dokumentasi penulis)

Menurut Damanhuri \& Padmi (2015), hanya $60 \%$ sampah yang berasal dari kota-kota besar di Indonesia dapat terangkut ke tempat pembuangan sampah akhir (TPA).

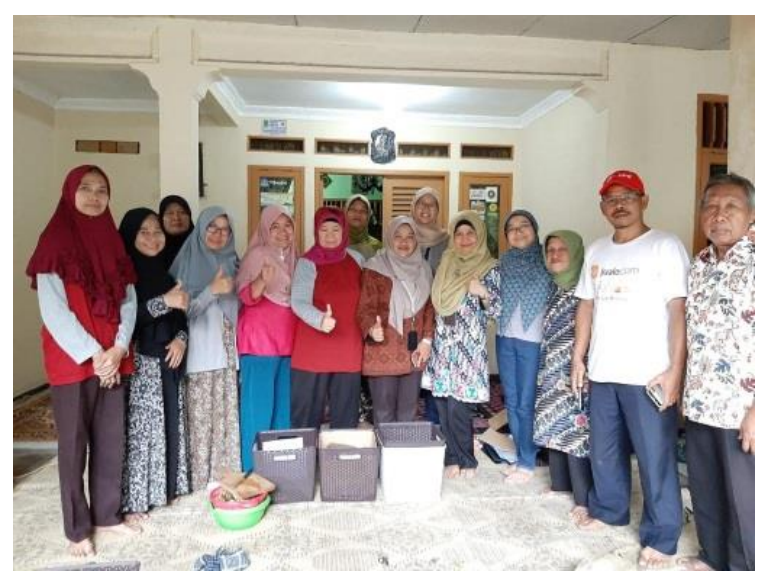

Gambar 3. Tim Dosen PKM Univ.Bakrie bersama Warga masyarakat RT 01 RW 06, Kelurahan Kreo Tangerang Peserta Pelatihan Pengolahan Sampah Organik

(Sumber: dokumentasi penulis)

\section{KESIMPULAN}

Kesimpulan dari kegiatan Edukasi Pengelolaan Sampah Domestik dalam Mewujudkan Kampung Hijau Mandiri di RT 01 RW 06, Kelurahan Kreo, Tangerang dapat dituliskan sebagai berikut. Dari hasil diskusi dan tanya jawab pada kegiatan ini disimpulkan bahwa masyarakat mengetahui bagaimana mengelola sampah termasuk mengetahui cara pengolahan sampah rumah tangga khususnya sampah dapur. Keberhasilan dalam memperkenalkan komposter sederhana dalam membuat kompos berupa keranjang Takakura yang mudah untuk diterapkan di lingkungan rumah tangga, sehingga pengolahan sampah organik dapat dilakukan mulai dari sumber, yaitu lingkungan rumah tangga. Kegiatan ini dinilai cukup berhasil yang ditunjukkan dengan adanya semangat dan kemauan peserta pelatihan untuk melakukan pengelolaan sampah mulai dari rumah masing-masing dan adanya kesadaran, kepedulian pada kebersihan lingkungan mereka. Masyarakat berhasil mengolah sampah dapur mereka dengan cara membuat kompos menggunakan metode Keranjang Takakura yang sederhana, mudah, dan murah, sehingga adanya keterlibatan masyarakat dalam usaha pengelolaan sampah dan pelestarian lingkungan. Kegiatan ini memiliki kemungkinan keberlanjutan yang sangat besar karena para ibu rumah tangga dan kader posyandu di RT 01 RW 06 Kelurahan Kreo adalah pemangku kebijakan di rumah tangga yang berpengaruh di 
lingkungannya. Dari pelatihan, warga RT 01 RW 06 Kelurahan Kreo pun bersepakat untuk menginisiasi didirikannya Bank Sampah. Melalui Bank Sampah diharapkan sampah dapat dikelola dengan baik tidak lagi dibuang begitu saja, sehingga Kampung Hijau Madiri dapat terwujud di lingkungan RT 01 dan RW 06 Kelurahan Kreo yang bersih, sehat dan nyaman. Kebersihan lingkungan merupakan salah satu kriteria Kampung Hijau Mandiri.

\section{UCAPAN TERIMA KASIH}

Ucapan terima kasih kepada Lembaga Pengabdian kepada Masyarakat Universitas Bakrie yang telah menfasilitasi dan mendanai kegiatan ini.

\section{DAFTAR PUSTAKA}

Badan Pusat Statistik Kota Tangerang. (2018). Kecamatan Larangan Dalam Angka 2018. Tangerang: BPS Kota Tangerang.

Damanhuri, E. \& Padmi, T. (2015). Pengelolaan Sampah Terpadu. Bandung: Penerbit ITB. Japan International Cooperation Agency. Takakura Composting Method. Diakses dari https://www.jica.go.jp/english/our_work/th ematic_issues/management/study_takakur a.html.

Kurniawan, T.A., Puppim De Oliveira, J., Premakumara, D.G.J., Nagaishi, M. (2013). City-To-City Level Cooperation for Generating Urban Co-Benefits: The Case of Technological Cooperation in The Waste
Sector Between Surabaya (Indonesia) and Kitakyushu (Japan). Journal of Cleaner Production, 58, 43-50.

Madonna, S., \& Nursetyowati, P. (2019). Pelatihan Pengolahan Sampah Rumah Tangga Menggunakan Metoda Keranjang Takakura di Kelurahan Pancoran. Indonesian Journal of Social Responsibility, 1(01), 9-15.

Peraturan Pemerintah Republik Indonesia Nomor 81 Tahun 2012 Pengelolaan Sampah Rumah Tangga dan Sampah Sejenis Sampah Rumah Tangga. 12 Oktober 2012. Lembaran Negara Republik Indonesia Tahun 2012 Nomor 188. Jakarta.

Peraturan Menteri Pekerjaan Umum Republik Indonesia Nomor 03/Prt/M/2013 Penyelenggaraan Prasarana dan Sarana Persampahan dalam Penanganan Sampah Rumah Tangga dan Sampah Sejenis Sampah Rumah Tangga. 14 Maret 2013. Jakarta.

Soemirat, Juli. (2011). Kesehatan Lingkungan. Yogyakarta: Gadjah Mada University Press.

Tangerangkota.co.id. (2018, September 14). 98 Wilayah Telah Dibentuk Kampung Hijau. Diakses dari https://www.tangerangkota.go. id/berita/detail/16671/98-wilayah-telah-dib entuk-kampung-hijau

Tchobanoglous G., Theisen H., Vigil S.A. (1993). Integrated Solid Waste Management. New York: McGraw Hill Inc.

Undang-undang Nomor 18 Tahun 2008 Pengelolaan Sampah. 7 Mei 2008. Jakarta. 
Indonesian Journal for Social Responsibility (IJSR) Vol. 2, No. 02, (2020), hal. 59-67 